\title{
Does Financial Crisis Give Impacts on Bahrain Islamic Banking Performance? A Panel Regression Analysis
}

\author{
Sutan Emir Hidayat ${ }^{1} \&$ Muhamad Abduh ${ }^{2}$ \\ ${ }^{1}$ University College of Bahrain, Manama, Bahrain \\ ${ }^{2}$ IIUM Institute of Islamic Banking and Finance, International Islamic University Malaysia, Kuala Lumpur, \\ Malaysia \\ Correspondence: Sutan Emir Hidayat, University College of Bahrain, Manama, Bahrain. Tel: 973-17-790-828. \\ E-mail: sutan@ucb.edu.bh
}

\author{
Received: May 13, 2012 \\ Accepted: May 31, 2012 \\ Published: July 1, 2012 \\ doi:10.5539/ijef.v4n7p79 \\ URL: http://dx.doi.org/10.5539/ijef.v4n7p79
}

\begin{abstract}
The 2007/2008 global financial crisis has given a significant impact on the performance of banking industry worldwide. The objective of this study is to see the impact of global financial crisis towards the financial performance of Islamic banking industry in Bahrain. Moreover, it also utilizes bank specific factors as predictors for Islamic bank performance in Bahrain. Panel regression is used to analyze the data. The result shows that LTA, LEQ, and LOHE are significant bank specific factors to influence Islamic bank performance in Bahrain. In addition, there is no significant impact of financial crisis upon the financial performance during the crisis period; however, it does affect the financial performance of Bahrain Islamic banking industry after the crisis period.
\end{abstract}

Keywords: financial crisis, Islamic banking, bank performance, panel regression, Bahrain

\section{Introducation}

The 2008 global financial crisis that started in the U.S. in late 2007 has given a wide array of impacts to the operating and financial performance of many banks all over the world (Ellaboudy, 2010; Smolo and Mirakhor, 2010; Kassim and Majid, 2010). As a result, many banks across the world reported financial loss on their financial report due to their connections with subprime mortgage in the U.S. or were simply affected by economic recession in their own countries. The impact of the crisis have even forced around 123 banks in the U.S. to file for bankruptcy in the year, including American giant bank Lehman Brother that was never been expected to fail.

As one of the results, the financial crisis has raised public's interest on Islamic banks since they are said to be relatively much less affected by the crisis. A number of experts and officials of Islamic banks have even claimed that Islamic banks are either not or less affected by the global financial crisis than conventional peers due to the nature of Islamic banking in which all financial transactions must be trade-based and asset-linked (Smolo and Mirakhor, 2010; Kassim and Majid, 2010; Ahmed, 2010).

It is even argued that if the principles of Islamic finance had been followed, the financial crisis would have been prevented (Ahmed, 2009). Consequently, there is a general belief that the financial intermediaries in the interest-free banking system are more stable compared to the conventional banking system (Kaleem, 2000; Kia and Darrat, 2003; Samad, 2004). Even though the claims need to be empirically proven, it is becoming a trend now that after the crisis more people are interested to know Islamic finance and its principles as applied in Islamic banks than ever before. For an example, the Vatican has called for reliance upon Islamic finance principles in financial dealings (Totaro, 2009)

After almost forty years, Islamic banks are currently spread all over the world both in Muslim and non Muslim countries. One of the countries which has a significant role towards the development of Islamic banking and finance is Bahrain which has started Islamic banking industry since 1979. Bahrain is notably considered as the most developed country in term of Islamic finance infrastructure within the Gulf Cooperation Council (GCC) (Wilson, 2009). The kingdom actively promotes itself as an international hub for Islamic finance. In order to achieve this goal, the Central Bank of Bahrain (CBB), through its comprehensive regulatory framework, opens its gate to local and international Islamic financial institutions to operate within the country. Bahrain is also the host to several organizations central to the development of Islamic finance i.e. the Accounting and Auditing Organization for Islamic Financial Institutions (AAOIFI), Liquidity Management Centre (LMC), the International Islamic Financial 
Market (IIFM), and the Islamic International Rating Agency (IIRA).

With a long history of banking industry, particularly Islamic banking industry, this paper is aimed at investigating the impact of financial crisis towards Islamic banking performance in Bahrain. This study is expected to give a significant contribution towards the existing literatures on the relationship between financial crisis and banking financial performance, particularly in the Islamic banking industry of Bahrain.

\section{Literature Review}

\subsection{Bahraini Banking Sector}

Bahrain is a tiny island-kingdom in the Middle East. Beside the oil and gas sector, the financial services sector is among the highest contributors to the country's overall GDP. According to the Central Bank of Bahrain's (CBB) annual report 2011, the sector contributed $25 \%$ to GDP of the country in 2010. Up to June 2011, the number of financial institutions in the country is 411 and the total financial sector workforce is 14,137 . The banking system in the Kingdom of Bahrain is considered as being the largest component of the financial system. Bahrain's banking sector has remained to be a cornerstone for growth of the domestic economy. The banking sector represents over $85 \%$ of total financial assets (El-Quqa et.al, 2007). Furthermore, the banking system compromises both Conventional and Islamic banks. The Conventional sector includes retails banks, specialized banks, wholesale banks and representative offices of overseas banks. On the other hand, the Islamic sector consists of retail banks and wholesale banks which offer as host of Sharia compliant products and services. The sole regulator for financial system in Bahrain is the CBB.

Up to December 2010, there are 6 Islamic retail banks and 18 Islamic wholesale banks operating in the kingdom (Hidayat, 2010). The high numbers of Islamic banks shows high profile of the country as the leading Islamic financial center in the region. In 2011, Islamic banks accounted for around 12\% of Bahrain's banking sector (Winton, 2011). Table 1 below summarizes Bahraini financial sector.

Table 1. Bahrain Financial Sector

\begin{tabular}{ll}
\hline \multicolumn{1}{c}{ The Key Economic Indicators: } & \multicolumn{1}{c}{ Banking Sector: } \\
\hline GDP (Current) US\$21.9 billion (2010) & Assets US\$197.5 billion (May 2011) \\
Growth -13.5\% & No. of institutions 134 (May 2011) \\
GDP (Constant) US\$13.6 billion (2010) & Retail banks 30 \\
Growth 4.6\% & Locally incorporated 15 \\
Financial Sector contribution to GDP 25\% & Branches of foreign banks 15 \\
Sovereign rating : & Wholesale banks 77 \\
BBB (S\&P Dec 2010) with negative watch & Representative Offices 27 \\
BBB (Fitch Dec 2010) with negative outlook & Islamic Banks (included in above): \\
Population 1,106,509 (2008) & No. of banks 27 (May 2011) \\
& Assets US\$24.5 billion \\
\hline
\end{tabular}

Source: Central Bank of Bahrain Report (2011).

The importance of Islamic banking can be further substantiated with the increasing contribution of Islamic banking assets to the total banking system. The total assets of the Islamic banks have grown at a much faster rate than the Bahrain banking system assets. As a result, the contribution of Islamic banking to total assets increased from 4.1\% in 2003 to $6.5 \%$ in 2006. Going forward, it is believed that Islamic banks will continue to grow at a faster pace than the conventional banking assets, as many investors are migrating from conventional banking to Islamic banking (El-Quqa et.al, 2007).

\subsection{The Impact of Financial Crisis on Banking Performance}

Based on the authors' observations, there are relatively few numbers of studies that compare the impacts of financial crisis into Islamic and conventional banking performance. Kaleem (2000) analyzes the Malaysian data over the period of January 1994 to December 1999 in order to investigate the performance of Islamic and conventional banks in pre and post global financial crisis 1997-1998. The study concludes that the Islamic banking system is more crises-proofed compared to the conventional banking system due to its asset-linked nature. Although the study 
claims that the analysis is for pre and post crisis, the time period used in the study is not reflecting the post crisis since the impacts of the 1997/1998 global financial crisis still lasted until beyond the year of 1999 .

Kassim and Majid, (2010) conduct a study aimed to arrive at empirical evidences on the impact of financial shocks (the 1997 and the 2007 financial crises) on the Islamic banks vis-a-vis the conventional banks in Malaysia. The study finds mixed evidences on the impact of the macroeconomic shocks on the Islamic and conventional banks. While the results based on the descriptive statistics indicate that the Islamic banks are relatively resilient to the financial shocks, the results based on the more robust econometric analysis reveal otherwise. The results based on the IRF analysis show that the Islamic financing responded significantly to macroeconomic shocks in non-crisis and 2007 crisis periods. The VDA results suggest that both Islamic and conventional banks are vulnerable to financial shocks.

Hassan and Dridi (2010) compare the performance of Islamic banks (IBs) and conventional banks (CBs) during the recent global crisis by looking at the impact of the crisis on profitability, credit and asset growth, and external ratings in a group of countries where the two types of banks have significant market share. The study suggests that IBs have been affected differently than CBs. Factors related to IBs'business model helped limit the adverse impact on profitability in 2008 , while weaknesses in risk management practices in some IBs led to a larger decline in profitability in 2009 compared to CBs. IBs' credit and asset growth performed better than did that of CBs in 2008-09, contributing to financial and economic stability. External rating agencies're-assessment of IBs'risk was generally more favorable.

Beck et al (2010) compare the performance of conventional and Islamic banks during the recent global crisis by looking at the impact of the crisis on business orientation, efficiency, asset quality, and stability in countries with data on at least four banks. The study suggests that Islamic banks seem more cost-effective than conventional banks in a broad cross-country sample. On the other hand, conventional banks seem more cost-effective than Islamic banks in a sample of countries with both Islamic and conventional banks. However, conventional banks that operate in countries with a higher market share of Islamic banks are more cost-effective but less stable. There is also consistent evidence of higher capitalization of Islamic banks and this capital cushion plus higher liquidity reserves explain the relatively better performance of Islamic banks during the recent crisis.

Based on the above previous studies, it is clear that none of the above studies that compare the impacts of financial crisis in Bahrain and other GCC countries. Therefore this study tries to fill the gap by investigating empirically the impact of financial crisis towards the banking performance for both Islamic and conventional banking industry in Bahrain. In general, like other GCC banks, banks in Bahrain were not as much directly exposed to the securitized and structured financial products (Ellaboudy, 2010). Therefore, Bahraini banks are expected to be generally less impacted by the recent global financial crisis than other emerging economies. The abundance of financial resources for Bahrain and other GCC countries, in addition to the initial macro intervention policies taken by Bahraini government, should help to mitigate the adverse impact of the current global financial crisis (Ellaboudy, 2010).

\subsection{Banking Performance Determinants}

In order to investigate the impact of financial crisis towards the banking performance, it is very important to understand the determinants of banking financial performance. Literatures reveal that banking financial performance is influenced by internal and external determinants (Bashir, 2000; Haron, 2004; Al-Kassim, 2007; Zantioti, 2009). Literatures also reveal that ROA and ROE are very important indicators of banking financial performance (profitability) and normally used as the dependent variables (Bashir, 2000, Burhonov, 2006; Al-Kassim, 2007; Zantioti, 2009). Literatures also reveal that among the internal factors that influence banking performance are bank size, leverage, loans, short-term funding, overhead, and ownership (equity) (Bashir, 2000; Haron, 2004; Burhonov, 2006; Al-Kassim, 2007). GDP per capita is the external variable that is usually included in banking financial performance literatures (Bashir, 2000; Burhonov, 2006; Zantioti, 2009).

Bashir (2000) found that Islamic banks financial performance is positively related to equity and loans (financings). Consequently, if financing and equity are high, Islamic banks should be more profitable. The study also finds that leverage is positively related profitability. The results also indicate that favorable macro-economic conditions (GDP per capita) help profitability. Haron (2004) found that expenditures (expenses) and profitability measures have a positive relationship. The study also suggests that size of the Islamic banks only had a significant positive relationship with one of performance indicators but was not significant with other profitability measures. Burhonov (2006) found unclear relationship between short-term funding to the profitability indicators. The regression results also show that the impact of macroeconomic variables, GDP per capita on the profitability measures is not conclusive. Alkassim (2007) finds that ROA for Islamic banks in GCC has positive coefficients with total assets and total expenses. Zantioti (2009) found that equity/total assets and GDP per capita statistically give positive significant 
impacts on Islamic bank profitability.

Based on the above previous studies, this study uses ROA and ROE as the dependent variables and bank size, leverage, loans, short-term funding, overhead expenses, ownership (equity) and GDP per capita as the independent variables. In order to examine the impact of the crisis into financial performance of Islamic and conventional banking in Bahrain, the study uses dummy variable for financial crisis where the financial crisis period takes 1 and other periods take 0 . The study also uses dummy Islamic to capture the performance of Islamic banks where 1 is for Islamic and o is for conventional banks. The above literatures also reveal the following hypotheses (Table 2).

Table 2. Description of the Variables Used in the Regression Analysis

\begin{tabular}{|c|c|c|}
\hline Variables & Description & $\begin{array}{l}\text { Hypothesized } \\
\text { Relationship with } \\
\text { Profitability }\end{array}$ \\
\hline ROA (Dependent) & $\begin{array}{l}\text { The Return on Average Total Assets of } \\
\text { Bank } j \text { in year } t\end{array}$ & NA \\
\hline ROE (Dependent) & $\begin{array}{l}\text { The Return on Average Shareholders' } \\
\text { Equity of Bank } j \text { in year } t\end{array}$ & NA \\
\hline LNTA (Internal Independent) & The logarithmic of total assets of $j$ in year $t$ & $(+)$ \\
\hline LEV (Internal Independent) & The leverage of bank $j$ in year $t$ & $(+)$ \\
\hline FIN (Internal Independent) & The loans/financings of bank $j$ in year $t$ & $(+)$ \\
\hline SF (Internal Independent) & The short-term funding of bank $j$ in year $t$ & $(-)$ \\
\hline OHE (Internal Independent) & The overhead expenses of bank $j$ in year $t$ & $(+)$ \\
\hline Equity (Internal Independent) & $\begin{array}{l}\text { The total shareholders' equity of bank } j \text { in } \\
\text { year } t\end{array}$ & $(+)$ \\
\hline GDPPC (External Independent) & The GDP per capita of country $j$ in year $t$ & $(+)$ \\
\hline DUMCRISIS (Dummy) & $\begin{array}{l}\text { A dummy variable for financial crisis (1) } \\
\text { and others }(0) \text {. }\end{array}$ & $(-)$ \\
\hline DUMTRAN (Dummy) & $\begin{array}{l}\text { A dummy variable for a period after } \\
\text { financial crisis (1) and others }(0) \text {. }\end{array}$ & $(+/-)$ \\
\hline
\end{tabular}

\section{Data and Method}

\subsection{Data}

Based on the data available in Bankscope Bureu van Dijk database, in 2011, there are 14 conventional banks and 23 Islamic banks in Bahrain. However, only 8 Islamic banks had completely reported financial statements from 2005-2010 periods. Therefore, this study uses the available data as samples in order to investigate the impacts of the financial crisis upon the financial performance of Islamic banking in Bahrain.

To achieve the objective of this study, DUMCRISIS and DUMTRAN are included in the regression model. DUMCRISIS is dummy variable for the event of global financial crisis and DUMTRAN is dummy variable to capture the performance of Bahraini Islamic banking sector after the global financial crisis. Table 3 depicts the summary statistics of dependent and independent variables used in this study. 
Table 3. Summary Statistics of Dependent and Explanatory Variables

\begin{tabular}{lrrrrrrrr}
\hline & ROE & ROA & LGDP & LFIN & LTA & LLEV & LOHE & LEQ \\
\hline Mean & 1.405 & 0.182 & 10.01 & 4.959 & 6.898 & 6.164 & 3.539 & 5.715 \\
Max. & 61.02 & 53.09 & 10.26 & 9.215 & 9.673 & 9.516 & 6.429 & 7.506 \\
Min. & -127.2 & -45.31 & 9.795 & -0.693 & 3.833 & 1.932 & 0.916 & 3.532 \\
Std. Dev. & 35.63 & 15.89 & 0.165 & 2.523 & 1.506 & 2.185 & 1.559 & 1.069 \\
\hline
\end{tabular}

\subsection{Econometric Specification}

To test the relationship between Islamic bank performance and the bank specific and macroeconomic determinants described earlier, following is the estimated linear regression model:

$$
y_{r j t}=\delta_{t}+\alpha_{j t} X_{i j t}+\beta_{i t} X_{e j t}+\varepsilon_{j t}
$$

where $\mathrm{j}$ refers to an individual Islamic bank; $\mathrm{t}$ refers to year, yrjt refers to the return on asset $(\mathrm{r}=1)$ and return on equity ( $\mathrm{r}=2$ ) and is the observation of bank $\mathrm{j}$ in a particular year $\mathrm{t}$; Xi represents the internal factors or determinants of a bank; Xe represents the external factors or macroeconomic determinants; and $\varepsilon_{j t}$ is a normally distributed random variable disturbance term.

The two main approaches to the fitting of models using panel data are known as fixed effects regressions and random effects regression. Basically, random effects model is more attractive because observed characteristics that remain constant for each individual are retained in the regression model. In fixed effects estimation, they have to be dropped. Also, with random effects estimation we do not lose $\mathrm{n}$ degrees of freedom, as is the case with fixed effects. However, if either of the preconditions for using random effects is violated, we should use fixed effects instead (Dougherty, 2007). One precondition is that the observations can be described as being drawn randomly from a given population. The other precondition is that the unobserved effect be distributed independently of the $\mathrm{Xj}$ variables.

By extending equation (1) to reflect the variables, as described in Table 1, the baseline model is formulated as follows:

$$
\begin{array}{r}
R O A_{j t}=\delta_{0}+\alpha_{1} L T A_{j t}+\alpha_{2} L F I N_{j t}+\alpha_{3} L L E V_{j t}+\alpha_{4} L O H E_{j t}+\alpha_{5} L E Q_{j t} \\
+\beta_{1} L G D P_{j t}+\beta_{2} D U M C R I S I S_{j t}+\beta_{1} D \operatorname{LMTRAN}_{j t}+\varepsilon_{j t}
\end{array}
$$

and,

\section{Empirical Findings}

$$
\begin{aligned}
R O E_{j t}=\delta_{0}+ & \alpha_{1} L T A_{j t}+\alpha_{2} L F I N_{j t}+\alpha_{3} L L E V_{j t}+\alpha_{4} L O H E_{j t}+\alpha_{5} L E Q_{j t} \\
& +\beta_{1} L G D P_{j t}+\beta_{2} D U_{M C R I S I S}+\beta_{1} D U M T R A N_{j t}+\varepsilon_{j t}
\end{aligned}
$$

\subsection{Pooled OLS Regression}

Pooled OLS regression is when we put all the data together and do not make any distinction between cross section and time series and then run a regression over all the data using ordinary least squares. Pooled OLS is often used as a rough and ready means of analyzing the data. It is a simple and quick standard to which more sophisticated regressions can be compared. 
Table 4. Summary of Pooled OLS Output

\begin{tabular}{|c|c|c|c|c|c|c|}
\hline Dependent Variable & \multicolumn{3}{|c|}{ ROA } & \multicolumn{3}{|c|}{ ROE } \\
\hline $\begin{array}{c}\text { Independent } \\
\text { Variable }\end{array}$ & Coefficient & t-Statistic & Prob. & Coefficient & t-Statistic & Prob. \\
\hline $\mathrm{C}$ & -155.163 & -0.497 & 0.621 & -568.920 & -0.950 & 0.347 \\
\hline DUMCRISIS & -6.469 & -0.586 & 0.561 & -12.947 & -0.611 & 0.545 \\
\hline DUMTRAN & -14.629 & -1.498 & 0.142 & -33.477 & -1.786 & $0.082^{*}$ \\
\hline LGDP & 12.129 & 0.380 & 0.706 & 50.484 & 0.825 & 0.415 \\
\hline LFIN & -0.798 & -0.369 & 0.714 & 5.334 & 1.287 & 0.206 \\
\hline LTA & -11.811 & -1.499 & 0.142 & -40.129 & -2.655 & $0.011^{* *}$ \\
\hline LLEV & 5.798 & 1.367 & 0.179 & 11.695 & 1.437 & 0.159 \\
\hline LEQ & 19.552 & 2.649 & $0.012 * *$ & 55.811 & 3.942 & $0.001 * * *$ \\
\hline LOHE & -6.643 & -1.827 & $0.075^{*}$ & -18.571 & -2.662 & $0.011 * *$ \\
\hline R-squared & \multicolumn{3}{|c|}{0.251} & \multicolumn{3}{|c|}{0.451} \\
\hline Adjusted R-squared & \multicolumn{3}{|c|}{0.098} & \multicolumn{3}{|c|}{0.339} \\
\hline F-statistic & \multicolumn{3}{|c|}{1.634} & \multicolumn{3}{|c|}{4.008} \\
\hline Prob(F-statistic) & \multicolumn{3}{|c|}{0.147} & \multicolumn{3}{|c|}{$0.002 * * *$} \\
\hline
\end{tabular}

Note: * significant at $\alpha=10 \%$; ** significant at $\alpha=5 \%$; ** significant at $\alpha=1 \%$;

Table 4 shows the summary of the pooled OLS results. For model one, whereby ROA is the dependent variable, none of the bank-specific explanatory variables are significant except for LEQ and LOHE. Variable of LEQ is significant at 5 percent alpha and positively affecting ROA. However, variable of LOHE is significant at 10 percent alpha and negatively affecting ROA. It can also be seen that global financial crisis and macroeconomic performance give no significant impact towards Bahraini Islamic banking ROA. Unfortunately, the probability of F-statistic of the model shows that overall the model developed in model one is not significant, thus it is not suggested for this study to rely upon this model.

In model two, with ROE as dependent variable, there are four explanatory variables which are significantly affecting the ROE i.e. LOHE, LEQ, LTA and post crisis situation (DUMTRAN). While LTA and LOHE are both significant at 5 percent alpha and negatively affecting Islamic banking ROE, the role of LEQ in affecting ROE is significant at 1 percent alpha and positively related. Interestingly, although the global financial crisis did not give any significant impact during its time, but it is shown in the model that the crisis impact upon Islamic banking ROE takes place after the crisis period.

The next step is to run the Breusch-Pagan Lagrangian Multiplier (LM) test in order to confirm whether it is enough with pooled OLS or needs to go for random and fixed effects panel data analysis. The LM test formula is as given below:

$$
L M=\frac{N T}{2(T-1)}\left[\frac{\sum_{i=1}^{N}\left(\sum_{t=1}^{T} \hat{\varepsilon}_{i t}\right)^{2}}{\sum_{i=1}^{N} \sum_{t=1}^{T} \hat{\varepsilon}^{2}{ }^{2}}-1\right]^{2}
$$

where $\mathrm{N}$ is the number of Islamic banks included in the analysis and $\mathrm{T}$ is the time period used in this study. The epsilon $\varepsilon$ is the residuals produced by the pooled OLS regression. In this test, LM is following the chi-square distribution with one degree of freedom under the null hypothesis.

The calculated LM statistics for model one and model two are 1.641 and 2.087 respectively. Since those values are greater than the tabulated chi-squared value with one degree of freedom and 5 percent alpha which is 0.003 , thus it is recommended in this study to further analyze the data, in both models, using random effects model in panel data 
analysis.

\subsection{Random Effects Model}

After confirming that the Breusch-Pagan LM test shows that random effects model is preferable than pooled OLS model, the next step is to build the random effects model for the same dependent and independent variables. Interestingly, every time we run the analysis, the results are always insignificant until we drop the variable of DUMCRISIS. Thus, the variable of DUMCRISIS is not included in this random effects model. Table 5 shows the results of random effects model.

Similar to model one in pooled OLS model, the significant independent variables in model one using random effects model are also LEQ and LOHE. But still, from the F-statistic value resulted, it indicates that overall the model is not significant. In model two, whereas ROE is the dependent variable, the significant bank-specific variables are LTA, LEQ, and LOHE and significant macroeconomic variable is the post-crisis situation. The F-statistic resulted in model two shows that overall the model is significant in 1 percent alpha. The model confirms that the profitability of Islamic banks in Bahrain is reducing after the crisis event. The industry might have resilient during the crisis but it is not after the crisis. The impact is felt by Islamic banks after the crisis.

Based on table 5 below it is found that LTA is significantly negatively correlated with ROE. One possible reason why LTA has negative correlation with ROE can be explained by Dupont analysis. Dupont analysis decomposes ROE into three components namely net profit margin (NPM), total assets turnover (TATO) and equity multiplier (EM). TATO is computed by dividing sales with total assets. It is clear that as higher the total assets given the same amount of sales as lower the TATO. As a result of lower TATO, the ROE is also lower. Therefore, higher asset which is not followed by the increase in sales and profitability results in lower ROE. On the other hand, LEQ has significant and positive correlation with ROE. This finding surprisingly contradicts ROE formula itself. Based on ROE formula, the equity should have negative correlation with ROE. However, the positive correlation might be found when the utilization of equity funds is very efficient leading to much higher net income than the increase in equity.

Table 5. Summary of Random Effects Output

\begin{tabular}{l|rrl|rrl}
\hline Dependent Variable & \multicolumn{3}{|c|}{ ROA } & \multicolumn{3}{c}{ ROE } \\
\hline Independent Variable & Coefficient & t-Statistic & Prob. & Coefficient & t-Statistic & Prob. \\
\hline C & 6.169 & 0.042 & 0.967 & -246.065 & -0.854 & 0.398 \\
DUMTRAN & -10.159 & -1.654 & 0.106 & -24.533 & -2.048 & $0.047^{* *}$ \\
LGDP & -4.254 & -0.275 & 0.785 & 17.695 & 0.586 & 0.561 \\
LFIN & -0.841 & -0.387 & 0.701 & 5.249 & 1.239 & 0.223 \\
LTA & -12.294 & -1.559 & 0.127 & -41.095 & -2.673 & $0.011^{* *}$ \\
LLEV & 6.094 & 1.438 & 0.158 & 12.286 & 1.486 & 0.145 \\
LEQ & 19.908 & 2.690 & $0.010^{* *}$ & 56.523 & 3.915 & $0.001^{* * *}$ \\
LOHE & -6.803 & -1.865 & $0.069^{*}$ & -18.891 & -2.654 & $0.011^{* *}$ \\
\hline R-squared & & 0.244 & & & 0.446 & \\
Adjusted R-squared & & 0.112 & & & 0.349 & \\
F-statistic & & 1.848 & & & & \\
Prob(F-statistic) & & 0.105 & & & 0.099 & \\
\hline
\end{tabular}

Note: * significant at $\alpha=10 \%$; ** significant at $\alpha=5 \%$; *** significant at $\alpha=1 \%$;

The Hausman test is done in order to see whether random effects are okay in some sense and equally consistent with fixed effects. Under the null, both are consistent, but one is more efficient; under the alternative, the more efficient of the two becomes inconsistent but the less efficient remains consistent. Thus if the null is okay, the two estimators should be similar; divergence indicates rejection of the null. The Hausman test probability values for both models are greater than 0.05 which indicates that random effect is preferable than fixed effects. Thus, fixed effects model is not tested. 


\section{Conclusion and Suggestion}

This study is aimed to investigate the impact of the changes in internal bank-specific variables and external macroeconomics variables towards Islamic banks' financial performance in Bahrain during and after the global financial crisis. The results depict that those independent variables are good predictor for ROE but not for ROA. The Breusch-Pagan Lagrangian Multiplier and Haussman test show that random effects model is better than pooled OLS and fixed effects model respectively. The random effects model shows that total assets, equity, and overhead expenses are significant predictors for Islamic banks' financial performance. In addition, DUMTRAN is also significantly affecting the financial performance. This shows that Islamic banking industry is not totally crisis-proof. Financial crisis does give an impact upon the Islamic banking performance, particularly in Bahrain, but the effect comes after the crisis period.

This study is not without limitation. There are at least two limitations in this study, which are: (i) samples are only taken from Bahrain, and (ii) it does not include the analysis on conventional banking. Thus, suggestions for future researches are; (i) apply similar study to other countries which have Islamic banking industry and (ii) incorporate also the analysis on conventional banking so that we can compare the impact of crisis to both types of bank.

\section{References}

Ahmed, A. (2010). Global financial crisis: An Islamic finance perspective. International Journal of Islamic and Middle Eastern Finance and Management, 3(4), 306-320. http://dx.doi.org/10.1108/17538391011093252

Ahmed, H. (2009). Financial Crisis: Risks and Lessons for Islamic Finance. ISRA International Journal of Islamic Finance, 1(1), 7-32. Retrieved from: www.kantakji.com/fiqh/Files/Markets/c47.pdf

Alkassim, F. (2007). The Profitability of Islamic and Conventional Banking in The GCC Countries: A Comparative Study. Bangor, UK: University of Wales.

Bashir, A. H. (2000). Assessing the Performance of Islamic Banks: Some Evidence from the Middle East. ERF's 8th Annual Meeting. Amman. Retrieved from: http://www.mafhoum.com/press/48E1.htm

Beck,T., Kunt, A. D., \& Merrouche, O. (2010). Islamic vs. Conventional Banking: Business Model, Efficiency and Stability. World Bank Policy Research Working Paper No. 5446. Retrieved from: http://papers.ssrn.com/sol3/papers.cfm?abstract_id=1694335

Burhonov, J. (2006). Islamic Banking Operations of Commercial Banks Under Islamic Banking Scheme (IBS) of Malaysia: The Performance Analysis. Bangkok: Faculty of Economics, Thammasat University. Retrived from: econ.tu.ac.th/thesis/2549/eng/jahongirbek.pdf

CBB. (2011). Financial Sector Fact Sheet. Manama: CBB.

Dougherty, C. (2007). Introduction to Econometrics. Oxford University Press.

Ellaboudy, S. (2010). The Global Financial Crisis: Economic Impact on GCC Countries and Policy Implications. International Research Journal of Finance and Economics, 41, 177-190. Retrieved from: www.eurojournals.com/IRJFE_41_14.pdf

El-Quqa, O. M., Hasan, F., Alsahli, K., \& Ahmed, N. (2009). Sukuk market-Down but not out. MENA Sukuk Report. Kuwait: Global Investment House. Retrieved from: www.kantakji.com/fiqh/Files/Markets/f145.pdf

Haron, S. (2004). Determinants of Islamic Bank Profitability. The Global Journal of Finance and Economics. 1(1). Retrieved from: http://issuu.com/azizulaziz/docs/002-determinants_of_islamic_bank_profitability

Hasan, M., \& Dridi, J. (2010). The Effects of the Global Crisis on Islamic and Conventional Banks:A Comparative Study. IMF Working Paper Series. Retrieved from: www.imf.org/external/pubs/ft/wp/2010/wp10201.pdf

Hidayat, S. E. (2010). Bahraini Islamic Finance Outlook 2010: A Mixed Picture. Islamic Finance News, 7(46), 13-14.

Kaleem, A. (2000). Modelling Monetary Stability under Dual Banking System: The Case of Malaysia. International Journal of Islamic Financial Services, 2(1), 21-42.

Kassim, S., \& Majid, M. S. A. (2010). Impact of financial shocks on Islamic banks: Malaysian evidence during 1997 and 2007 financial crises. International Journal of Islamic and Middle Eastern Finance and Management, 3(4), 291-305. http://dx.doi.org/10.1108/17538391011093243

Kia, A., \& Darrat, A. F. (2003). Modeling Money Demand under the Profit-Sharing Banking Scheme: Evidence on Policy Invariance and Long-Run Stability. ERF's 10th Annual Conference. Marrakech, Morocco. Retrieved from: www.mafhoum.com/press7/193E13.pdf 
Samad, A. (2004). Performance of Interest-Free Islamic Banks vis-à-vis Interest-based Conventional Banks of Bahrain. IIUM Journal of Economics and Management, 12(2), 1-15. Retrieved from: iium.edu.my/enmjournal/122art1.pdf

Smolo, E., \& Mirakhor, A. (2010). The Global Financial Crisis and Its Implications for The Islamic Financial Industry. International Journal of Islamic and Middle Easterb Finance, 3(4), 372-385. http://dx.doi.org/10.1108/17538391011093306.

Totaro, L. (2009). Vatican Says Islamic Finance May Help Western Banks in Crisis. Rome: Bloomberg. Retrieved from: http://www.bloomberg.com/apps/news?pid=newsarchive\&sid=aOsOLE8uiNOg

Wilson, R. (2009). The Development of Islamic Finance in the GCC. [PowerPoint slides]. Retrieved from: http://www.cimaglobal.com/Study-with-us/Islamic-finance-qualifications/Islamic-finance-resources/Islamic-fin ance-articles/Development-of-Islamic-finance-in-the-GCC/

Winton, B. (2011). Bahrain: Back from the brink. Islamic Finance News, 8(48), 1-3.

Zantioti, L. E. (2009). Does Islamic Bank Performance Differ by Region? Unpublished Master Thesis, Stockholm School of Economics. Retrieved from: arc.hhs.se/download.aspx?MediumId=842 